\title{
EML4/ALK Fusion Gene Variant 2
}

National Cancer Institute

\section{Source}

National Cancer Institute. EML4IALK Fusion Gene Variant 2. NCI Thesaurus. Code C99726.

A fusion gene ( 4.7 kb) that results from a chromosomal inversion inv(2)(p21p23) which fuses exon 20 of the EML4 gene with exons 20-29 of the ALK gene. This fusion is associated with non-small cell lung cancer. 